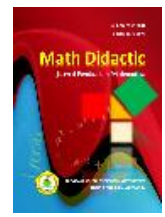

MATH DIDACTIC: JURNAL PENDIDIKAN MATEMATIKA

Volume 4 Nomor 1, Januari - April 2018, halaman 68 - 78

Tersedia Daring pada http://jurnal.stkipbjm.ac.id/index.php/math

\title{
PENGGUNAAN PERMAINAN PUZZLE PADA MATERI BANGUN DATAR DI KELAS VII SMP NEGERI 12 YOGYAKARTA
}

\section{USE OF PUZZLE GAME ON TWO-DIMENTIONAL FIGURE FOR $7^{\text {th }}$ SMP NEGERI 12 YOGYAKARTA}

\author{
Noor Laila Atini \\ STKIP PGRI Banjarmasin \\ noorlailaatini@gmail.com
}

\begin{abstract}
Abstrak: Penelitian ini bertujuan untuk mendeskripsikan bagaimana aktivitas siswa dalam penerapan media permainan puzzle pada materi bangun datar di kelas VII SMP Negeri 12 Yogyakarta. Selain itu, penelitian ini bertujuan juga untuk mengetahui hasil belajar serta respon siswa dengan penerapan media tersebut. Metode yang digunakan dalam penelitian ini adalah metode penelitian deskriptif. Penelitian dilaksanakan di SMP Negeri 12 Yogyakarta dengan jumlah siswa 36 orang. Teknik pengumpulan data yang digunakan meliputi tes, observasi, dan angket. Hasil penelitian ini menunjukkan bahwa penerapan media permainan puzzle pada materi bangun datar dapat dikatakan berhasil dengan baik, karena menghasilkan pengaruh positif bagi siswa. Hasil belajar siswa dengan media permainan puzzle memberikan peningkatan dilihat dari tingkat ketuntasannya. Selain itu respon siswa terhadap pembelajaran matematika dengan menggunakan permainan puzzle menunjukkan kualifikasi respon sangat kuat, artinya siswa merasa senang dan antusias dalam menerapkan permainan tersebut.
\end{abstract}

Kata Kunci: Media permainan puzzle, aktivitas, hasil belajar dan respon

Abstract: This study aims to describe how student activity in application of puzzle game media on the material wake flat in class VII SMP Negeri 12 Yogyakarta. In addition, this study also aims to determine the results of learning and student response with the application of these media. The method used in this research is descriptive research method. The study was conducted in SMP Negeri 12 Yogyakarta with 36 students. Data collection techniques used include tests, observations, and questionnaires. The results of this study indicate that the application of puzzle game media on the flat wake material can be said to work well, because it produces a positive influence for students. Students' learning outcomes with the puzzle game media provide an enhanced view of the completeness level. In addition, students' responses to learning mathematics by using puzzle games show very strong response qualifications, meaning students feel happy and enthusiastic in applying the game.

Keywords: Media puzzle game, activity, learning result and response

Cara Sitasi: Atini, N.L. (2018). Penggunaan permainan puzzle pada materi bangun datar di kelas VII SMP Negeri 12 Yogyakarta. Math Didactic: Jurnal Pendidikan Matematika, 4(1), 68-78. 
Tujuan pendidikan pada jenjang satuan pendidikan dasar berdasarkan Peraturan Pemerintah No.23 Tahun 2006 tentang Standar Kompetensi Lulusan adalah untuk meletakkan dasar kecerdasan, pengetahuan, kepribadian, akhlak mulia, serta keterampilan untuk hidup mandiri dan mengikuti pendidikan lebih lanjut. Peserta didik diharapkan memenuhi semua standar kompetensi lulusan agar dapat menempuh jenjang pendidikan yang selanjutnya dengan baik. Pencapaian standar kompetensi lulusan peserta didik adalah bergantung pada proses pembelajaran yang ditempuh peserta didik baik dalam pendidikan formal maupun informal.

Sekolah berperan penting dalam mengembangkan potensi anak menjadi manusia yang bermutu. Dalam rangka menciptakan sumber daya manusia yang bermutu diperlukan layanan pendidikan yang berorientasi pada kebutuhan siswa. Untuk membutuhkan manusia yang berkualitas dibutuhkan proses pendidikan yang berkualitas pula. Untuk itu salah satu upaya pemerintah dalam meningkatkan mutu pendidikan sekolah adalah perbaikan proses belajar mengajar yang berkualitas. Dalam Peraturan Pemerintah No.41 Tahun 2007 tentang Standar Proses, menyebutkan proses pembelajaran pada satuan pendidikan diselenggarakan secara interaktif, inspiratif, menyenangkan, menantang, memotivasi peserta didik untuk berpartisipasi aktif serta memberikan ruang yang cukup bagi prakarsa, kreativitas, dan kemandirian sesuai dengan bakat, minat, dan perkembangan fisik serta psikologi peserta didik.

Matematika merupakan mata pelajaran pokok di setiap satuan pendidikan, mulai dari
Sekolah Dasar (SD) sampai dengan perguruan tinggi. Berbagai kebijakan telah ditetapkan oleh pemerintah untuk meningkatkan mutu pendidikan dengan melakukan perubahan pada kurikulum, peningkatan kualitas guru,dan penambahan sarana dan prasarana yang mendukung kegiatan belajar mengajar. Pemerintah juga menuntut kepada para pemerhati pendidikan untuk meningkatkan kualitas lembaga, pengajar (guru), dan peserta didik (siswa) supaya dapat bersaing dalam kompetensinya masing-masing.

Hadi (2005, hal. 12) menjelaskan proses pembelajaran matematika yang selama ini terjadi belum sesuai dengan yang diharapkan. Beberapa hal yang menjadi ciri praktek pendidikan di Indonesia selama ini adalah pembelajaran yang berpusat pada guru (teacher centre). Guru menyampaikan materi dengan metode ceramah dan ekspositori sementara siswa mencatatnya pada buku catatan. Pembelajaran matematika seperti ini menyebabkan siswa mengalami kesulitan untuk memahami materi pelajaran matematika yang abstrak. Kondisi ini mengakibatkan mata pelajaran matematika masih dipandang sebagai mata pelajaran yang sulit oleh para pelajar maupun masyarakat umumnya (Orton, 2004, hal. 178).

Seorang guru bertugas memberikan pembelajaran yang bermakna, menyenangkan, kreatif dan dialogis (Shuterland, 2007, hal. 52). Oleh karena itu seorang guru dituntut harus profesional dalam menjalankan tugasnya sebagai pendidik. Hal ini berarti setiap guru perlu mengembangkan potensi, kreativitas, dan inisiatif yang ada pada dirinya untuk mengantisipasi segala bentuk perubahan yang terjadi dalam sains dan teknologi. Dengan demikian pada pengelolaan 
perencanaan pembelajaran, guru sebagai manajer dalam proses pembelajaran dituntut untuk melakukan perencanaan pembelajaran yang inovatif, menarik dan juga menyenangkan.

Dalam Standar Isi Pendidikan Matematika di SMP No.22 Tahun 2006, mata pelajaran matematika pada satuan pendidikan meliputi aspek-aspek: bilangan, aljabar, geometri dan pengukuran, serta statistika dan peluang. Geometri merupakan salah satu materi di antara beberapa materi pelajaran matematika terutama pada materi segiempat dan segitiga. Pada materi ini siswa telah dikenalkan dengan simbol-simbol dan angkaangka yang menyatakan bilangan tertentu serta garis dan gambar. Trianto (2009, hal. 18), menyatakan dalam kurikulum di Indonesia terutama dalam mata pelajaran eksak (matematika, fisika, kimia) dalam pengajarannya selama ini terpatri kebiasaan dengan urutan sajian pembelajaran sebagai berikut: diajarkan teori/definisi/teorema, diberikan contoh-contoh, dan diberikan latihan soal. Kondisi seperti ini tidak akan menumbuhkembangkan aspek kemampuan dan aktivitas siswa seperti yang diharapkan. Akibatnya nilai-nilai yang didapat tidak seperti yang diharapkan.

Berdasarkan hasil wawancara dengan guru matematika SMP Negeri 12 Yogyakarta, mengatakan bahwa pembelajaran geometri termasuk pembelajaran yang membosankan bagi siswanya (khususnya materi bangun datar segiempat dan segitiga). Mengamati proses belajar mengajar di lapangan, pada umumnya sebagian besar pembelajaran segiempat dan segitiga di SMP Negeri 12 Yogyakarta didominasi oleh guru atau teacher center dimana guru menjadi satu-satunya sebagai sumber pengetahuan. Guru selalu menggunakan metode ceramah sebagai sarana mengajar sehingga membuat siswa cepat bosan, mengantuk bahkan siswa tidak mudah memahami pelajaran dari guru sehingga siswa pun menjadi pasif.. Salah satu materi yang cukup sulit dalam pembelajaran matematika adalah geometri. Hal tersebut terungkap dari ketuntasan hanya mencapai $65 \%$ saja. Padahal secara klasikal sekolah tersebut menetapkan ketuntasan sebesar $70 \%$ dari jumlah keseluruhan siswa yang tuntas. Di sinilah pentingnya peranan seorang guru karena harus mampu menjadi inisiator bagi siswanya. Guru inisiator adalah guru yang mampu mengetahui dan memahami siswa dari berbagai kondisi,lingkungan permainan, bakat, kecenderungan, kondisi orang tua, mata pelajaran, keberhasilan dan kegagalan serta hal-hal lainnya yang menyangkut kepribadian dan kehidupan siswa.

\section{Metode merupakan bagian dari} komponen pengajaran yang menduduki posisi penting selain tujuan, guru, peserta didik, media, lingkungan, dan evaluasi. Dalam kata lain proses pembelajaran dapat dikatakan sulit mencapai hasil dan tujuan manakala guru tidak menggunakan metode yang tepat sesuai karakteristik materi pembelajaran. Banyak variasi dari metode pembelajaran yang dapat diberikan kepada peserta didik agar mereka bisa memahami apa yang disampaikan sehingga tidak mengalami jenuh maupun bosan seperti memberikan suatu permainan, teka-teki, atau point bagi siswa yang bisa menjawab pertanyaan serta memberikan gambar-gambar yang berkaitan dengan pelajaran.

Banyak faktor yang dapat menunjang keberhasilan siswa dalam mempelajari 
matematika, salah satunya dengan menggunakan metode yang menyenangkan, yaitu permainan matematika. Sekolah Menengah Pertama (SMP) khususnya kelas VII merupakan masa peralihan dari Sekolah Dasar (SD). Oleh sebab itu tidak heran jika jiwa dan pemikiran mereka masih tergolong anak-anak. Usia seperti mereka itu sangat cocok menerapkan metode permainan dimana peserta didik nantinya akan dilibatkan secara aktif bermain dalam situasi nyata yang berkaitan dengan matematika khususnya bangun datar. Dengan metode permainan peserta didik akan terhibur sehingga perhatiannya lebih fokus. Dengan metode ini pula siswa lebih cepat ingat dan hafal apa yang sudah dipelajari karena konsep matematika yang abstrak diubah menjadi lebih konkret.

Puzzle adalah salah satu permainan yang dapat digunakan untuk menarik perhatian siswa dalam belajar matematika khususnya untuk materi bangun datar. Dari permainan ini siswa terlibat langsung untuk menyusun dan memainkannya, sehingga diharapkan pembelajaran lebih menarik dan bermakna. Dengan demikian tujuan pembelajaran dapat tercapai dengan baik dan bermanfaat untuk mereka baik di masa sekarang maupun masa yang akan datang (Sya'ban Jamil, 2009, hal. 169). Penerapan metode permainan ini belum pernah dilakukan oleh guru yang bersangkutan di SMP Negeri 12 Yogyakarta.

Berdasarkan uraian di atas, maka peneliti tertarik untuk melakukan penelitian dengan judul "Penggunaan Permainan Puzzle Pada Materi Bangun Datar di Kelas VII SMP Negeri 12 Yogyakarta" .

Permainan puzzle yang dimaksud dalam penelitian ini adalah adopsi dari permainan Tangram atau lebih dikenal dengan istilah puzzle cina karena permainan ini dikembangkan pertama kali di negeri cina pada masa dinasti Tang. Istilah tangram pertama kali dikenalkan oleh Thomas Hill dalam bukunya yang berjudul “Geometrical Puzzle For The Youth “ pada tahun 1848. Tangram adalah sebuah permainan dengan cara memindahkan lempengan-lempengan berbentuk segitiga, persegi dan jajar genjang untuk membentuk berbagai macam bangun datar menyerupai orang, binatang, rumah, kapal, dll termasuk persegi panjang, persegi, jajargenjang maupun trapesium. Tangram terdiri atas 5 segitiga, 1 persegi, dan 1 jajar genjang. Adapun kegunaan permainan tangram itu sendiri yaitu untuk melatih kemampuan dan kecepatan berpikir serta melatih dalam mengembangkan kreativitas anak.

Tangram merupakan permainan puzzle yang sangat menyenangkan. Tangram sendiri banyak tersedia di pasaran, tetapi dapat juga dengan mudah di buat sendiri dengan cara memotong kertas menurut pola garis tertentu. Di sini Peneliti memodifikasi permainan tangram tersebut sesuai dengan keperluan penelitian. Contoh pola tangram dapat dilihat pada gambar 1 berikut ini.

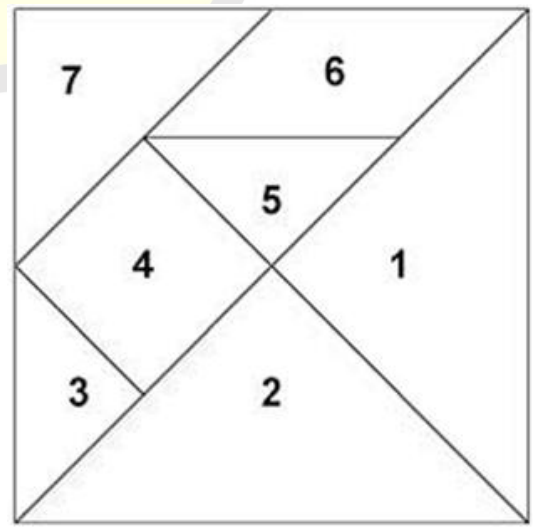

Gambar 1. Tangram 
Dari ketujuh potongan tangram tersebut, siswa diminta untuk menyusun sehingga membentuk bangun persegi, persegi panjang, jajar genjang dan trapesium. Dalam permainan puzzle di sini, media yang diperlukan adalah papan permainan puzzle yang sudah dirangkai bingkai-bingkainya dengan satuan centi meter $(\mathrm{cm})$ dan potonganpotongan puzzle tersebut yang polanya diambil dari tangram. Apabila potongan-potongan tersebut telah disusun membentuk persegi panjang, persegi, jajargenjang, dan trapesium, kemudian diletakkan sisinya di papan permainan maka dapat kita ketahui panjang sisi-sisi bangun tersebut sehingga dapat dihitung luas dan kelilingnya menggunakan rumusnya masing-masing.

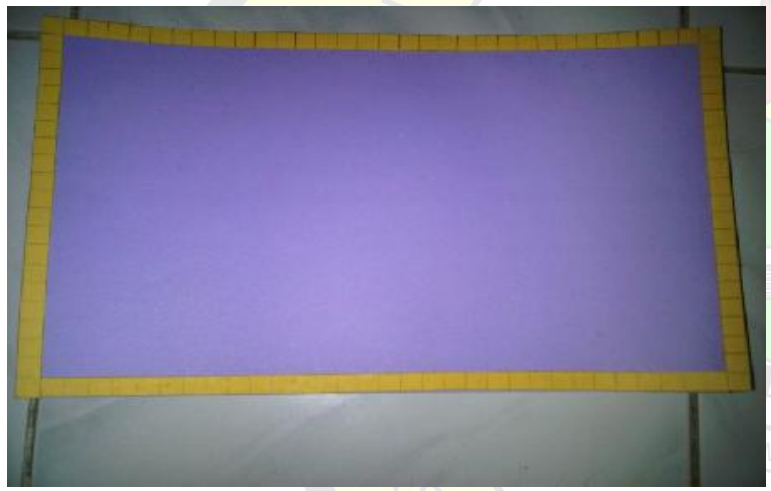

Gambar 2. Papan permainan puzzle

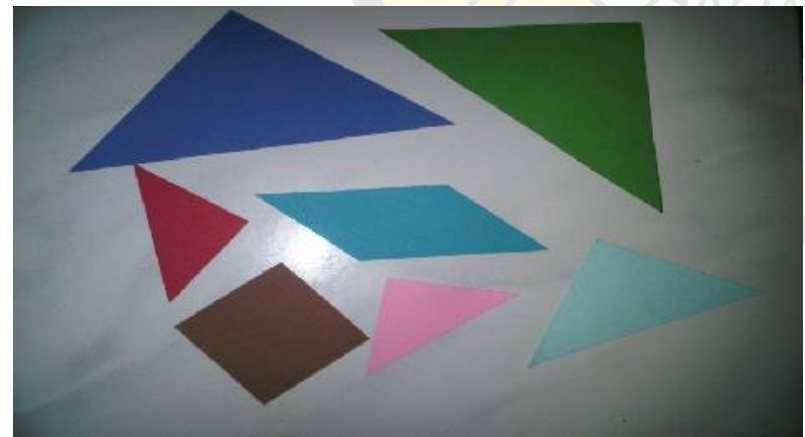

Gambar 3. Potongan-potongan puzzle

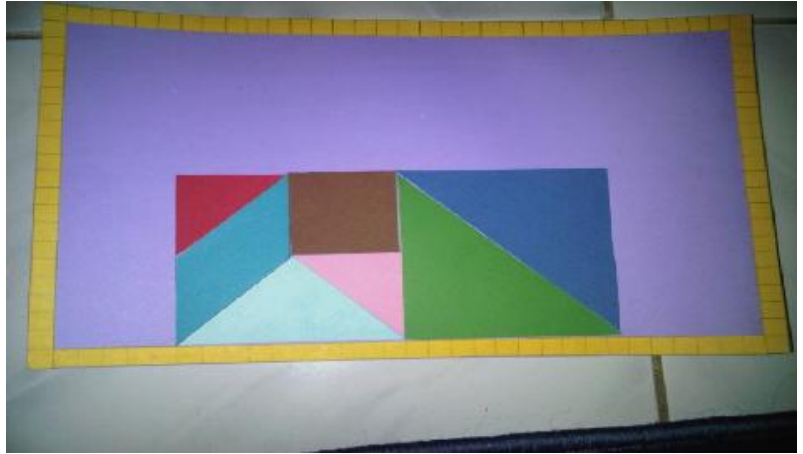

Gambar 4. Persegi panjang

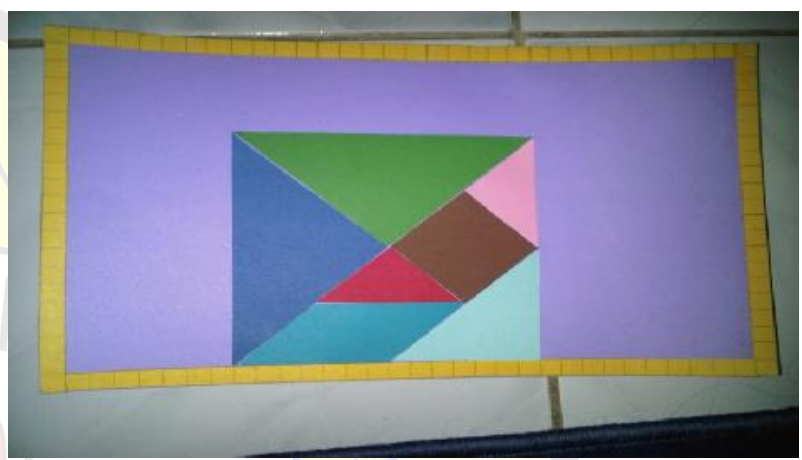

Gambar 5. Persegi

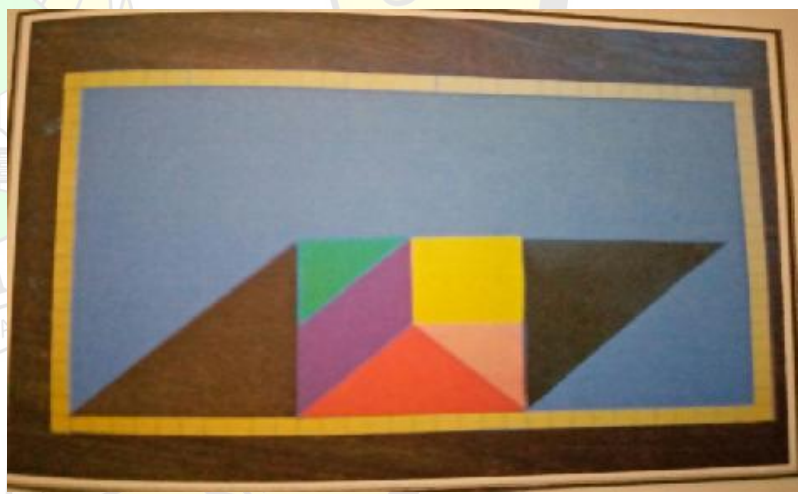

Gambar 6. Jajar genjang

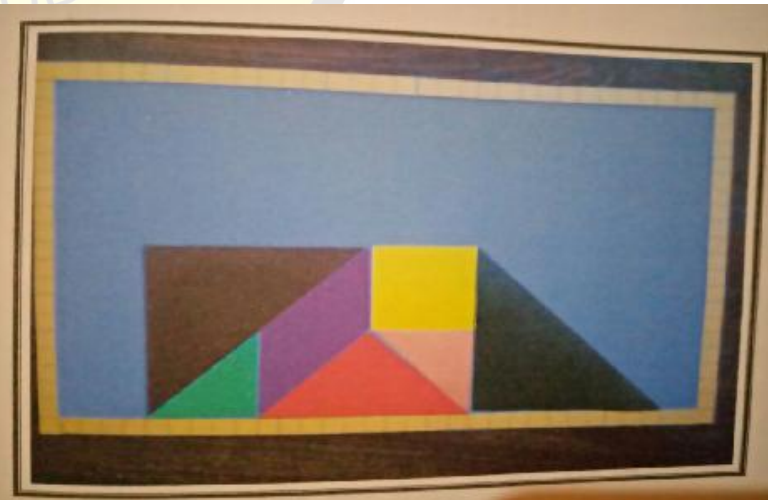

Gambar 7. Trapesium siku-siku 


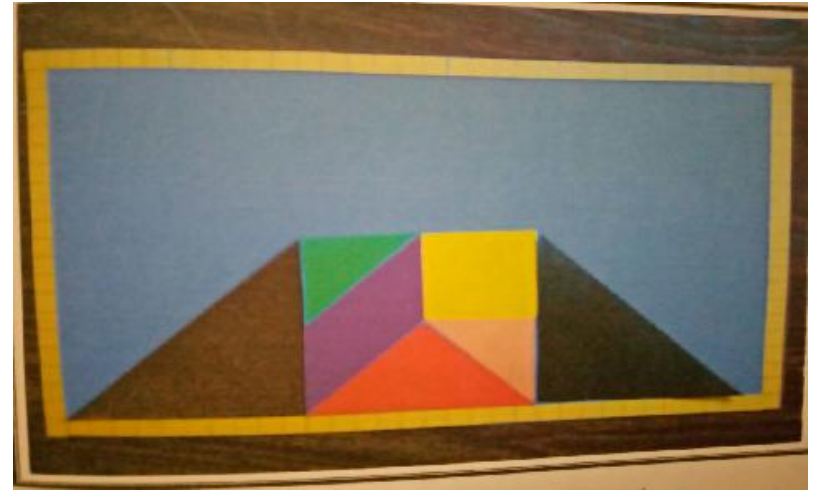

Gambar 8. Trapesium sama kaki

\section{Metode Penelitian}

Metode yang digunakan dalam penelitian ini adalah metode deskriptif, yaitu suatu metode yang meneliti status kelompok manusia, suatu objek, suatu set kondisi, suatu sistem pemikiran, ataupun suatu kelas peristiwa pada masa sekarang yang bertujuan untuk membuat deskripsi, gambaran, atau lukisan secara sistematis, faktual, dan akurat mengenai fakta-fakta, sifat-sifat serta hubungan antara fenomena yang diselidiki (Nazir, 2005, hal. 59).

Penelitian ini dilaksanakan pada bulan Mei di SMP Negeri 12 Yogyakarta dengan subjek penelitian ini adalah siswa kelas VIIA SMP Negeri 12 Yogyakarta yang berjumlah 36 orang. Objek yang ingin diteliti adalah aktivitas, hasil, dan respon siswa dalam menggunakan permainan puzzle pada materi bangun datar. Teknik pengumpulan data pada penelitian ini adalah observasi, tes dan angket.

Data yang telah terkumpul dianalisis dengan menggunakan sistem analisis sebagai berikut.

1. Analisis Data Aktivitas Siswa

Data aktivitas siswa diperoleh melalui observasi terhadap siswa dengan memperhatikan kegiatan siswa selama pelajaran berlangsung kemudian disimpulkan dengan melihat hasil

ketentuan penilaian observer.

2. Analisis Data Hasil Belajar Siswa

Penilaian hasil belajar siswa secara individu menggunakan rumus berikut.

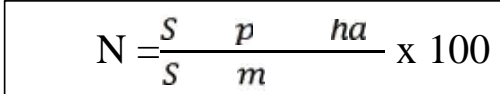

(Usman dan Setiawati, 2001)

Keterangan: $\mathrm{N}=$ Nilai akhir siswa

Nilai akhir yang diperoleh siswa kemudian dikelompokkan menggunakan kriteria pada tabel berikut.

Tabel 1. Kualifikasi Hasil Belajar Siswa

\begin{tabular}{llc}
\hline No & \multicolumn{1}{c}{ Kualifikasi } & Nilai \\
\hline 1 & Istimewa & $\geq 95,0$ \\
\hline 2 & Amat Baik & $80,0-94,9$ \\
\hline 3 & Baik & $65,0-79,9$ \\
\hline 4 & Cukup & $55,0-64,9$ \\
\hline 5 & Kurang & $40,1-54,9$ \\
\hline 6 & Amat Kurang & $<40,0$ \\
\hline
\end{tabular}

( Depdiknas, 2004 )

3. Analisis Data Respon Siswa

Teknik yang digunakan untuk menganalisis respon belajar siswa terhadap permainan puzzle berdasarkan hasil angket menggunakan rumus berikut.

$$
\mathrm{P}=\frac{t}{N} \times 100 \%
$$

(Sudjiono, 2009)

Keterangan:

$\mathrm{P}=$ Persentase respon siswa

$\mathrm{f}=$ frekuensi

$\mathrm{N}=$ Banyaknya siswa

Angka persen yang diperoleh dari hasil angket tersebut kemudian diinterpretasikan menggunakan kriteria pada tabel berikut. 
Tabel 2. Interpretasi Respon Siswa

\begin{tabular}{llc}
\hline No & Interpretasi & \multicolumn{1}{l}{ Persentase } \\
\hline 1 & Sangat lemah & $0 \%-20 \%$ \\
\hline 2 & Lemah & $21 \%-40 \%$ \\
\hline 3 & Cukup & $41 \%-60 \%$ \\
\hline 4 & Kuat & $61 \%-80 \%$ \\
\hline 5 & Sangat kuat & $81 \%-100 \%$ \\
\hline \multicolumn{2}{c}{ ( Riduan, 2008) }
\end{tabular}

\section{Hasil Penelitian dan Pembahasan}

Penelitian ini dilaksanakan di kelas VII A SMP Negeri 12 Yogyakarta dengan jumlah siswa 36 orang sejak tanggal $12 \mathrm{Mei}-20 \mathrm{Mei}$. Penelitian ini dilaksanakan dalam 5 kali pertemuan dengan alokasi waktu $2 \times 40$ menit setiap pertemuan. Di bawah ini indikator dan kegiatan penelitian untuk setiap pertemuan.

A. Pertemuan pertama ( $12 \mathrm{Mei}$ )

Indikator :

1. Mengidentifikasi sifat-sifat persegi panjang

2. Menghitung keliling dan luas bangun persegi panjang

3. Mengidentifikasi sifat-sifat persegi

Kegiatan Penelitian :

1. Kegiatan belajar mengajar

2. Pengenalan permainan puzzle persegi panjang dan persegi

B. Pertemuan kedua (13 Mei )

Indikator :

1. Menghitung keliling dan luas bangun persegi

2. Tes 1

Kegiatan Penelitian :

1. Menghitung keliling dan luas bangun persegi

2. Tes 1

Kegiatan Penelitian :

1. Kegiatan belajar mengajar

2. Pelaksanaan tes materi persegi panjang dan persegi

C. Pertemuan ketiga ( $15 \mathrm{Mei}$ )

Indikator :

1. Mengidentifikasi sifat-sifat jajar genjang

2. Menghitung keliling dan luas jajargenjang

3. Mengidentifikasi sifat-sifat trapesium

Kegiatan Penelitian :

1. Kegiatan belajar mengajar

2. Pengenalan permainan puzzle jajargenjang dan trapesium

D. Pertemuan keempat (19 Mei )

Indikator :

1. Menghitung keliling dan luas trapesium

2. Tes 2

Kegiatan Penelitian :

1. Kegiatan belajar mengajar

2. Pelaksanaan tes materi jajargenjang dan trapesium

E. Pertemuan kelima ( 20 Mei )

Indikator : Tes Akhir

Kegiatan Penelitian : Pemberian reward

\section{Hasil Penelitian}

1. Aktivitas siswa

Hasil penelitian yang akan dianalisis secara deskripsi adalah data aktivitas siswa selama pembelajaran dengan menggunakan permainan puzzle yang dapat diketahui menggunakan lembar observasi. Aktivitas siswa diamati oleh dua orang observer dengan aspek yang diamati meliputi:

1. Siswa memperhatikan penjelasan dari guru

2. Siswa menjawab pertanyaan dari guru

3. Siswa secara aktif maju ke depan 
mengerjakan soal-soal dari guru

4. Siswa memperhatikan pada saat guru memperkenalkan konsep bangun datar melalui permainan puzzle

5. Siswa melakukan permainan puzzle dengan tertib

6. Siswa bermain dengan sportif tanpa kecurangan selama permainan berlangsung

7. Keceriaan dan antusiasme siswa dalam pembelajaran dengan permainan puzzle

8. Siswa menanyakan hal yang belum jelas kepada guru

9. Siswa mengerjakan soal latihan yang diberikan

10. Siswa membuat kesimpulan terhadap materi yang dipelajari

Aspek tersebut dinilai dengan melakukan ceklis lembar observasi berdasarkan keterangan kualifikasi nilai (1) tidak baik, (2) kurang baik, (3) Cukup, (4) Baik, dan (5) Sangat Baik. Berikut Histogram hasil dari observer 1 dan observer 2 .

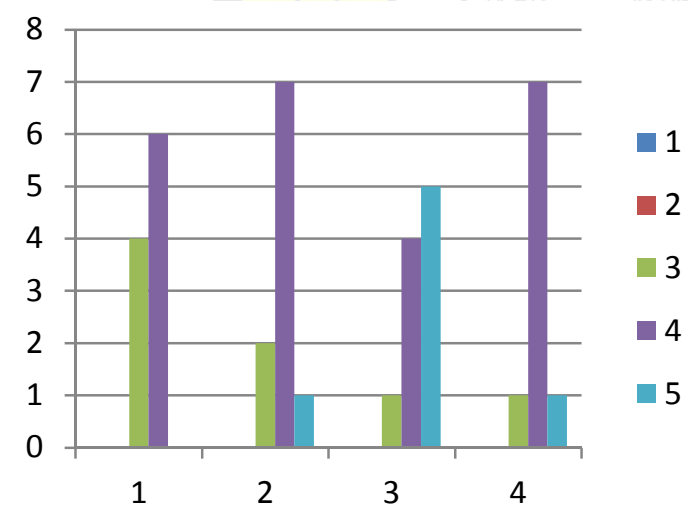

Gambar 7: Hasil pengamatan observer 1

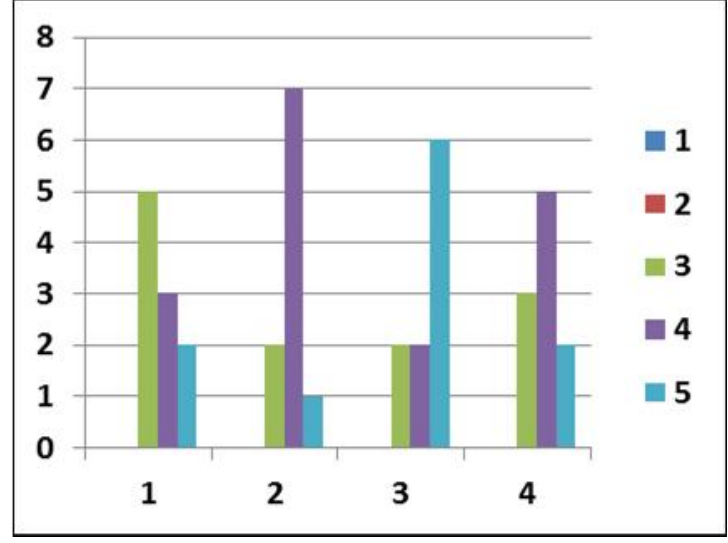

Gambar 8. Hasil pengamatan observer 2

Dari hasil penilaian observer 1 dapat dilihat bahwa modus kualifikasi nilai yang diberikan yaitu berkualifikasi baik demikian pula dengan hasil penilaian observer 2 yang rata rata menilai aktivitas siswa berjalan dengan baik.

Berdasarkan kedua gambar tersebut dapat diambil kesimpulan bahwa secara keseluruhan aktivitas siswa selama proses pembelajaran berlangsung dengan menggunakan permainan puzzle pada materi bangun datar dengan kualifikasi baik.

\section{Hasil Belajar Siswa}

Berdasarkan hasil penelitian, yang telah dilaksanakan, ada tiga tes hasil belajar siswa yang dapat dilihat pada tabel di bawah ini.

Tabel 3. Distribusi Frekuensi Hasil Belajar Siswa

\begin{tabular}{cccc}
\hline $\begin{array}{c}\text { Interval } \\
\text { nilai }\end{array}$ & $\begin{array}{c}\text { (Tes } \\
\text { pertama) } \\
\text { frekuensi }\end{array}$ & $\begin{array}{c}\text { (Tes } \\
\text { Kedua) } \\
\text { frekuensi }\end{array}$ & $\begin{array}{c}\text { (Tes } \\
\text { Akhir) } \\
\text { frekuensi }\end{array}$ \\
\hline $53-60$ & 2 & 1 & 0 \\
\hline $61-68$ & 3 & 0 & 0 \\
\hline $69-76$ & 9 & 10 & 4 \\
\hline $77-84$ & 11 & 0 & 5 \\
\hline $85-92$ & 8 & 13 & 8 \\
\hline $93-100$ & 3 & 12 & 19 \\
\hline Jumlah & 36 & 36 & 36 \\
\hline
\end{tabular}


Setelah mendapatkan hasil tersebut kemudian dianalisis untuk mengetahui ketercapaian KKM (Kriteria Ketuntasan Minimal) oleh sekolah dan guru matematika yakni sebesar 70. Adapun hasil keseluruhan tes untuk melihat berapa siswa yang tuntas dan tidak tuntas secara keseluruhan dapat dilihat dari tabel di bawah.

Tabel 4. Kualifikasi Ketuntasan Hasil Belajar Siswa

\begin{tabular}{ccccc}
\hline $\begin{array}{c}\text { Kualifi } \\
\text { kasi }\end{array}$ & $\begin{array}{c}\text { Tingkat } \\
\text { ketunta } \\
\text { san }\end{array}$ & $\begin{array}{l}\text { (Tes } \\
\text { perta } \\
\text { ma) } \\
\text { frekue } \\
\text { nsi }\end{array}$ & $\begin{array}{c}\text { (Tes } \\
\text { Kedua) } \\
\text { frekuen } \\
\text { si }\end{array}$ & $\begin{array}{c}\text { (Tes } \\
\text { Akhir } \\
\text { freku } \\
\text { freku } \\
\text { ensi }\end{array}$ \\
\hline Tuntas & $\geq 70$ & 32 & 35 & 36 \\
\hline $\begin{array}{c}\text { Tidak } \\
\text { Tuntas }\end{array}$ & $<70$ & 4 & 1 & 0 \\
\hline
\end{tabular}

Berdasarkan tes harian pertama diperoleh dari 36 siswa sebanyak 32 orang mencapai ketuntasan dan 4 orang yang belum tuntas atau dengan kata lain sekitar 88,9\% siswa dapat mencapai nilai KKM dengan nilai rata-rata keseluruhan sebesar 81,5. Untuk tes harian kedua lebih meningkat dari tes sebelumnya yaitu sebanyak 35 siswa dapat mencapai KKM atau sebesar 97,2 \% dengan nilai rata-rata 85,3 , sedangkan untuk tes akhir $100 \%$ siswa dapat memenuhi kriteria ketuntasan dengan nilai rata-ratanya 87,1.

\section{Respon Siswa}

Berdasarkan angket yang diberikan kepada siswa diperoleh data tentang respon siswa terhadap pembelajaran dengan menggunakan permainan puzzle. Persentase yang diperoleh siswa dengan respon pilihan "YA" yaitu sebagai berikut .

1. Apakah saat guru memberikan materi pembelajaran, kamu dapat memahaminya dengan baik? ( $100 \%$, kualifikasi sangat kuat )

2. Apakah kamu dapat memahami aturan dalam permainan puzzle? ( 97,2\%), kualifikasi sangat kuat )

3. Apakah kamu merasa senang belajar matematika pada materi bangun datar dengan menggunakan permainan puzzle? ( $97,2 \%$, kualifikasi sangat kuat )

4. Apakah kamu lebih bersemangat untuk belajar matematika setelah melakukan permainan puzzle? ( $100 \%$, sangat kuat )

5. Apakah kamu jujur dalam bermain? $97,2 \%$, sangat kuat )

6. Apakah menyusun puzzle membentuk bangun datar merupakan hal yang mudah bagi kamu? ( $66,7 \%$, kuat )

7. Apakah kamu dapat menghitung keliling dan luas daerah puzzle yang berhasil kamu susun? ( $86,1 \%$, sangat kuat )

8. Apakah kamu senang jika kamu menjadi pemenang dalam permainan? (100\% , sangat kuat )

9. Apakah kamu tidak merasa kesal pada saat teman kamu yang menjadi pemenang? ( $91,7 \%$, sangat kuat )

10. Apakah kamu tidak bosan, jika selama beberapa kali kamu tidak pernah menjadi pemenang? ( 8,3\%, sangat lemah )

Dari perolehan angket di atas terlihat bahwa setelah melaksanakan pembelajaran bangun datar menggunakan permainan puzzle, respon siswa secara keseluruhan sekitar 84,4 $\%$ sangat kuat. Siswa terlihat senang, bersemangat, dan termotivasi dalam belajar matematika karena mereka dapat belajar sekaligus bermain. Peneliti juga sempat menanyakan langsung dengan siswa bahwa mereka tidak merasa bosan memainkannya walaupun mereka tidak menjadi pemenang, karena menurut siswa permainan puzzle ini 
memberikan tantangan yang luar biasa dalam pembelajaran matematika.

Dengan adanya respon yang sangat kuat ini diharapkan dapat memberikan alasan bagi sekolah dan guru matematika untuk menggunakan pembelajaran menarik yang salah satunya dengan permainan puzzle pada materi bangun datar atau permainan lain yang sesuai dengan materi pembelajaran sehingga pada akhirnya diharapkan mampu meningkatkan hasil belajar siswa.

\section{Simpulan dan Saran}

\section{Simpulan}

Berdasarkan hasil dan pembahasan, dapat disimpulkan

1. Aktivitas siswa selama proses pembelajaran berlangsung secara keseluruhan menunjukkan kualifikasi baik.

2. Hasil belajar siswa dalam pembelajaran bangun datar yang terdiri dari persegi panjang, persegi, jajargenjang, dan trapesium dengan menggunakan permainan puzzle secara keseluruhan dapat mencapai ketuntasan.

3. Respon Siswa terhadap pembelajaran bangun datar dengan permainan puzzle termasuk dalam kualifikasi sangat kuat, artinya siswa sangat senang dan antusias dalam belajar matematika.

\section{Saran}

Berdasarkan kesimpulan di atas, maka saran yang dapat diberikan yaitu.

1. Dalam pembelajaran matematika sekalikali diterapkan metode permainan agar suasana belajar menjadi senang,tidak jenuh dan tidak bosan sehingga pembelajaran dapat bervariasi dan tidak monoton.

2. Dengan adanya penelitian ini diharapkan dapat memberikan motivasi terhadap siswa untuk lebih menyenangi pelajaran matematika sehingga mampu meningkatkan hasil belajar siswa.

\section{Daftar Pustaka}

Hadi, S.2005. Pendidikan Matematika Realistik dan Implementasinya. Yogyakarta: Pustaka Belajar

Jamil, S. 2009. 101 Games Cerdas \& Kreatif. Jakarta: Penebar plus

Nazir, M. 2005. Metode Penelitian. Jakarta: Ghalia Indonesia

Orton, A.. 2004. Learning mathematics ( $3^{\text {rd }}$ ed). Issues, theory, and classroom practice. London, New York: British library

Presiden 2007. Peraturan Pemerintah RI Nomor 41, Tahun 2007, tentang Standar Proses.

Presiden 2006. Peraturan Pemerintah RI Nomor 22, Tahun 2006, tentang Standar Isi.

Presiden 2006. Peraturan Pemerintah RI Nomor 23, Tahun 2006, tentang Standar Kompetensi Lulusan

Riduwan. 2008. Belajar Mudah Penelitian Untuk Guru, Karyawan, dan Peneliti Pemula. Bandung: Alfabeta

Shuterland, R. 2007. Teaching for learning mathematics. New Yorrk: British library

Sudijono, A. 2008. Pengantar Statistik Pendidikan. Jakarta: PT Raja Grafindo Persada

Supatmono, C. 2009. Matematika asyik. Grasindo

Trianto. (2009). Mendesain model pembelajaran inovatif-progresif: konsep, landasan dan implementasinya pada kurikulum tingkat satuan pendidikan (KTSP). Jakarta: Kencana perdana media group 
Usman, U. \& L. Setiawati. 2001. Upaya Optimalisasi Kegiatan Belajar Mengajar. Bandung: PT Remaja Rosdakarya 